\title{
Prevalence of asthma and rhinitis symptoms among children living in Coimbra, Portugal
}

\section{Prevalência dos sintomas de asma e rinite nas crianças a viver em Coimbra, Portugal}

\author{
M. Muc ${ }^{\mathrm{a}, \mathrm{b}, *}$, A. Mota-Pinto ${ }^{\mathrm{c}}$, C. Padez ${ }^{\mathrm{a}, \mathrm{b}}$ \\ a Department of Life Sciences, University of Coimbra, Coimbra, Portugal \\ ${ }^{\mathrm{b}}$ Research Centre for Anthropology and Health, University of Coimbra, Portugal \\ c General Pathology Laboratory, Faculty of Medicine, University of Coimbra, Coimbra, Portugal
}

Asthma is the most common chronic disease in pediatrics. Most data on the prevalence of childhood allergic diseases come from the International Study of Asthma and Allergies in Childhood (ISAAC) phase II held in 1995 and phase III from 2002. ISAAC created a methodology for studying two age groups 6-7 and $13-14$ years old. ${ }^{1}$ In 2002 , according to the data gathered in the phase III of ISAAC, the prevalence of asthma among Portuguese children from 6 to 7 years old was $9.4 \%, 29.1 \%$ for rhinitis and $28.1 \%$ for wheezing. ${ }^{2}$

In the last decade, little information on the prevalence of childhood asthma and rhinitis in Portugal has been documented, and to the best of our knowledge, none in Coimbra. In 2002, 5 centers from 5 Portuguese cities joined the ISAAC project: Lisbon, Oporto, Coimbra, Portimão and Funchal. The Coimbra research center only studied 13-14 years old adolescents. $^{2}$

The district of Coimbra, with a total area of $3974 \mathrm{~km}^{2}$, is located in central Portugal and has 434,311 inhabitants. Coimbra is the biggest city in the central region, and the 6th largest in Portugal. ${ }^{3}$

The most recent published data on childhood asthma prevalence in Portugal come from the Lisbon 2008 study where the prevalence of asthma, allergic rhinitis and wheezing was $5.6 \%, 43.0 \%$ and $43.3 \%$, respectively, ${ }^{4}$ and from

\footnotetext{
* Corresponding author.

E-mail address: magdalenamuc@gmail.com (M. Muc).
}

Matosinhos (data from 2009) where the prevalence of asthma among the children $0-7$ years old was $9.56 \% .{ }^{5}$ A large national prevalence study based on The Portuguese National Asthma Survey reported the prevalence of $6.2 \%$ of current asthma for the Central region and $7.2 \%$ for the age group $<18$ years in the whole country. ${ }^{6}$

The objective of this study was to assess the prevalence of asthma and rhinitis in the population of 6-8 years old children from the district of Coimbra.

ISAAC based core asthma and rhinitis questionnaires, containing questions about the prevalence and frequency of asthma and rhinoconjunctivitis symptoms of a child in the past 12 months and in a lifetime, were handed into the legal guardians of children in the 1st and 2 nd grades of primary school in Coimbra. The Estimated number of children from the 1 st and 2 nd grade in the Coimbra district was 8200 (National Census 2011). The sample size was calculated based on the confidence interval of $95 \%$, prevalence of $10 \%{ }^{2}$ and for the narrow margin of error of $2 \%$ that a sample of 782 individuals would be enough.

The response rate was $65 \%(N=1063)$ and there was no significant difference between the private vs public schools $(p=0.88)$ as well as so among the urban, suburban and rural zones $(p=0.42)$. After excluding children with chronic disease as opposed to atopic, a sample of 1037 children from 32 schools (28 public and 4 private) in the Coimbra district were included in the analysis, $50.8 \%$ were girls and $49.2 \%$ boys $(95 \% \mathrm{Cl} 45.9-52.0)$, the mean age was 7.26 years old 
Table 1 Prevalence of asthma and rhinitis symptoms among 6-7 year old Portuguese children living in the district of Coimbra in 2012 estimated using the ISAAC tools in comparison to the data from Portuguese cities from 2002 obtained within the ISAAC phase III.

\begin{tabular}{|c|c|c|c|c|c|c|c|c|c|c|c|c|}
\hline & $\begin{array}{l}\text { Portugal } \\
6-7 \text { (2002) }\end{array}$ & $\begin{array}{l}\text { Portugal } \\
13-14 \\
(2002) \\
\end{array}$ & $\begin{array}{l}\text { Coimbra } \\
\text { 6-7 (2012) }\end{array}$ & $\begin{array}{l}\text { Coimbra } \\
13-14 \\
(2002) \\
\end{array}$ & $\begin{array}{l}\text { Oporto } \\
6-7 \text { (2002) }\end{array}$ & $\begin{array}{l}\text { Oporto } \\
13-14 \\
(2002) \\
\end{array}$ & $\begin{array}{l}\text { Lisbon } \\
6-7 \text { (2002) }\end{array}$ & $\begin{array}{l}\text { Lisbon } \\
13-14 \\
(2002) \\
\end{array}$ & $\begin{array}{l}\text { Portimão } \\
\text { 6-7 (2002) }\end{array}$ & $\begin{array}{l}\text { Portimão } \\
13-14 \\
(2002) \\
\end{array}$ & $\begin{array}{l}\text { Funchal } \\
6-7 \text { (2002) }\end{array}$ & $\begin{array}{l}\text { Funchal } \\
13-14 \\
(2002)\end{array}$ \\
\hline & Prevalence \% & & & & & & & & & & & \\
\hline Total $n$ & & & 1037 & 1177 & 2464 & 3336 & 2477 & 3024 & 1069 & 1109 & 1819 & 3161 \\
\hline Wheeze ever & $28.1(1512)$ & $21.8(2576)$ & $34.4(347)$ & $20.6(242)$ & $10.0(246)$ & $22.1(736)$ & $30.2(748)$ & $25.9(784)$ & $28.4(304)$ & $18.2(202)$ & $25.3(460)$ & $19.4(612)$ \\
\hline $\begin{array}{l}\text { Wheeze in the past } \\
12 \text { months }\end{array}$ & $12.9(692)$ & 11.8 (1398) & 11.9 (120) & 10.7 (126) & $2.3(56)$ & 13.1 (437) & $14.2(351)$ & $14.6(443)$ & $13.2(141)$ & 9.7 (108) & $11.0(200)$ & $9.0(284)$ \\
\hline $\begin{array}{l}4 \text { or more attacks of } \\
\text { wheeze in the past } \\
12 \text { months }\end{array}$ & & & $3.1(31)$ & $2.6(31)$ & $2.7(67)$ & $2.6(87)$ & $3.4(83)$ & $3.5(105)$ & $2.5(27)$ & $2.2(24)$ & $2.1(38)$ & $1.9(60)$ \\
\hline $\begin{array}{l}\text { Sleep disturbance } \\
\text { from wheeze, } 1 \text { or } \\
\text { more nights a week } \\
\text { in the past } 12 \\
\text { months }\end{array}$ & & & $2.2(22)$ & $1.0(12)$ & $2.5(61)$ & $1.5(51)$ & $3.4(84)$ & $2.1(62)$ & $3.6(38)$ & $1.8(20)$ & $4.1(74)$ & $1.5(46)$ \\
\hline $\begin{array}{l}\text { Speech limited by } \\
\text { wheeze in the past } \\
12 \text { months }\end{array}$ & & & $1.9(19)$ & $2.2(26)$ & $10.0(247)$ & $2.8(95)$ & $2.9(72)$ & $3.5(107)$ & $2.1(22)$ & $2.1(23)$ & $3.3(60)$ & $2.7(84)$ \\
\hline Asthma ever & $9.4(505)$ & 14.7 (1737) & $10.6(107)$ & $12.2(144)$ & $5.7(140)$ & $15.1(504)$ & $7.8(194)$ & $15.6(472)$ & $4.9(52)$ & $12.4(138)$ & $14.2(259)$ & $15.2(479)$ \\
\hline $\begin{array}{l}\text { Wheeze during or } \\
\text { after exercise in the } \\
\text { past } 12 \text { months }\end{array}$ & & & $6.4(65)$ & $19.5(229)$ & $30.8(759)$ & $21.0(701)$ & $7.1(176)$ & $24.8(751)$ & $5.5(59)$ & $18.2(202)$ & $7.0(117)$ & $21.2(670)$ \\
\hline $\begin{array}{l}\text { Night cough in the } \\
\text { past } 12 \text { months }\end{array}$ & & & $24.2(245)$ & $30.5(359)$ & $26.1(644)$ & 32.9 (1097) & 32.7 (809) & $35.4(1070)$ & $29.4(314)$ & $31.4(348)$ & 32.9 (599) & 34.1 (1079) \\
\hline Nose symptoms ever & $29.1(1565)$ & $37.1(4383)$ & $23.1(234)$ & $31.8(374)$ & $22.1(544)$ & $41.8(1394)$ & $31.2(774)$ & $39.7(1202)$ & $28.0(299)$ & $34.4(382)$ & $27.0(492)$ & $32.6(1031)$ \\
\hline $\begin{array}{l}\text { Nose symptoms in } \\
\text { the past } 12 \text { months }\end{array}$ & 24 (1291) & 26.5 (3131) & 19.7 (199) & $23.9(281)$ & 7.5 (186) & 31.7 (1056) & $26.3(651)$ & $29.0(878)$ & $23.1(247)$ & 21.7 (241) & $21.6(393)$ & $21.4(675)$ \\
\hline $\begin{array}{l}\text { Nose and eye } \\
\text { symptoms in the } \\
\text { past } 12 \text { months }\end{array}$ & & & $9.3(94)$ & $6.5(76)$ & $0.7(18)$ & $10.3(344)$ & $10.1(249)$ & $10.6(320)$ & $8.2(88)$ & $7.2(80)$ & $9.4(171)$ & $8.9(280)$ \\
\hline $\begin{array}{l}\text { Nose symptoms } \\
\text { affecting activities a } \\
\text { lot in the past } 12 \\
\text { months }\end{array}$ & & & $1.6(3)$ & $0.3(3)$ & $2.7(67)$ & $0.5(18)$ & $1.0(25)$ & $0.6(17)$ & $0.9(10)$ & $0.2(2)$ & $1.5(28)$ & $1.1(36)$ \\
\hline $\begin{array}{l}\text { Hayfever ever } \\
\text { Symptoms of rhino } \\
\text { conjunctivitis in the }\end{array}$ & $4.2(227)$ & 7.5 (134) & $\begin{array}{l}1(10) \\
18.4(186)\end{array}$ & $\begin{array}{l}14.0(165) \\
6.5(76)\end{array}$ & $\begin{array}{l}7.4(182) \\
16.8(413)\end{array}$ & $\begin{array}{l}5.0(168) \\
10.3(342)\end{array}$ & $\begin{array}{l}2.7(67) \\
10.0(247)\end{array}$ & $\begin{array}{l}6.4(194) \\
10.5(317)\end{array}$ & $\begin{array}{l}3.6(38) \\
7.9(84)\end{array}$ & $\begin{array}{l}7.3(81) \\
7.1(79)\end{array}$ & $\begin{array}{l}6.7(122) \\
9.2(167)\end{array}$ & $\begin{array}{l}8.7(275) \\
8.7(276)\end{array}$ \\
\hline
\end{tabular}


$(95 \% \mathrm{Cl} 7.22-7.30)$. As the attendance of children from urban zones was higher than expected (72\% compared to $57 \%$ for the district $^{3}$ ) we applied the post-stratification weights for the zone type. At least one episode of asthma in a lifetime was reported in $10.4 \%$ of the studied population $(95 \% \mathrm{Cl}$ 8.6-12.3). At least one wheezing episode was experienced by $35.2 \%(95 \% \mathrm{Cl} 32.3-38.2)$ of the studied children and $11.8 \%$ $(95 \% \mathrm{Cl} 9.8-13.8)$ had at least one attack within the past 12 months. Prevalence of lifetime rhinitis and current rhinitis was $22.8(95 \% \mathrm{Cl} 20.2-25.4)$ and $19.4(95 \% \mathrm{Cl} 17.0-21.9)$ respectively. In our study, the prevalence of lifetime asthma was $10.4 \%(95 \% \mathrm{Cl} 8.6-12.3)$ which is slightly higher than the national prevalence recorded in $2002(9.4 \%)$ and higher than most cities in 2002 with the exception of Funchal (14.2\%).

The national prevalence of wheezing in children aged 6-7 years old measured using the ISAAC tools in a lifetime in 2002 was $28.1 \%$. Our study revealed a very high prevalence of wheezing episodes at least once in child's life, $35.2 \%$ $(95 \% \mathrm{Cl} 32.3-38.2)$. This is not only higher than all of the values reported in 6-7 year old children in 2002, but also higher than all of the adolescent prevalence. ${ }^{2}$ Although the prevalence could be biased by the understanding of the term "wheeze" (in Portuguese "pieira"), which differs between the health specialists and parents, ${ }^{7}$ it is unlikely as the methodology used in all the studies was the same. There is no reason to think that the common understanding of this term could change significantly over a decade. With the lack of data from Coimbra center on our age group from both 1995 and 2002, and the 10 years interval between the studies, we cannot be sure if the prevalence increased during this period, or if Coimbra indeed has a higher prevalence of lifetime wheezing than other Portuguese cities.

In Lisbon, where a group of 342 students between 5 and 12 years of age participated in a study, the lifetime asthma rate was lower than in the phase III of ISAAC study $(5.6 \%$ compared to $7.8 \%$ in the phase III); however wheezing episodes occurring at least once in a lifetime were reported in $13.1 \%$ more children than in 2002. ${ }^{4}$ These results suggest that the wheeze prevalence could indeed be increasing among Portuguese children.

The prevalence comparisons between our study and data gathered during the phase III of ISAAC in Portugal are presented in Table 1.

It has been estimated that, in Portugal, we can expect 20,250 new cases of asthma annually. ${ }^{8}$ Asthma and allergic diseases continue to be a global health concern, and Portugal does not seem to be an exception.

\section{Ethical disclosures}

Protection of human and animal subjects. The authors declare that the procedures followed were in accordance with the regulations of the relevant clinical research ethics committee and with those of the Code of Ethics of the World Medical Association (Declaration of Helsinki).

Confidentiality of data. The authors declare that they have followed the protocols of their work center on the publication of patient data and that all the patients included in the study received sufficient information and gave their written informed consent to participate in the study.

Right to privacy and informed consent. The authors have obtained the written informed consent of the patients or subjects mentioned in the article. The corresponding author is in possession of this document.

\section{Funding}

This work was supported by a grant of the Fundação para a Ciência e a Tecnologia number SFRH/BD/66877/2009

\section{Conflicts of interest}

This work was supported by a grant of the Fundação para a Ciência e a Tecnologia number SFRH/BD/66877/2009.

\section{References}

1. Asher MI, Keil U, Anderson HR, Beasley R, Crane J, Martinez F, et al. International Study of Asthma and Allergies in Childhood (ISAAC): rationale and methods. Eur respir J. 1995;8:483-91.

2. Rosado Pinto J. ISAAC - 20 anos em Portugal. Acta Pediatr Port. 2011;42:S35-40.

3. Comissão de Coordenação e Desenvolvimento Regional do Centro, Caracterização socio-economica do Distrito de Coimbra [Socio-economic characterization of the district of Coimbra], August 2009 (https://www.ccdrc.pt/index.php? option=com_docman\&amp; task=doc_download\&amp; Itemid=91\&amp; gid=1106\&amp;lang=pt) (in Portuguese).

4. Pegas PN, Alves CA, Scotto MG, Evtyugina MG, Pio CA, Freitas MC. Factores de risco e prevalência de asma e rinite em crianças em idade escolar em Lisboa. Rev Port Pneumol. 2011;17:109-16.

5. de Sousa J, Santo M, Colaço T, Almada-Lobo F, Yaphe J. Asthma in an urban population in Portugal: A prevalence study. BMC Public Health. 2011;11:347.

6. Sa-Sousa A, Morais-Almeida M, Azevedo L, Carvalho R, Jacinto T, Todo-Bom A, et al. Prevalence of asthma in Portugal-The Portuguese National Asthma Survey. Clin Transl Allergy. 2012;2:15.

7. Fernandes R, Robalo B, Calado C, Medeiros S, Saianda A, Figueira $J$, et al. The meaning of wheezing for parents and health professionals: a questionnaire survey in Portuguese. BMC Pediatrics. 2011;11:112.

8. de Sousa JC, Silva ML, Lobo FA, Yaphe J. Asthma incidence and accuracy of diagnosis in the Portuguese sentinel practice network. Prim Care Respir J. 2010;19:352-7. 